\title{
Consolidation strategies of small family firms in Poland during the Covid-19 crisis
}

\author{
Andrzej Marjański, Łukasz Sułkowski
}

\begin{abstract}
A B S T R A C T
Objective: The objective of the article is to contribute to research into family businesses by understanding how small family businesses are responding and adapting to the Covid-19 crisis.

Research Design \& Methods: The research method is based on a comparative analysis of case studies. To investigate the impact of Covid-19 on small family businesses in Poland, we conducted exploratory studies in 12 entities, based on 29 partially structured interviews with managers of these companies.

Findings: The sudden spread of the Covid-19 pandemic around the world took many lives and caused severe restrictions in social and private life, including the business sector. While almost every firm has been affected by the pandemic crisis, small businesses, dominated by family businesses, are particularly vulnerable to it. Our findings show that the Covid-19 crisis affects all companies and presents a completely new challenge that has so far had no precedent. Small family businesses are not prepared for the prolonged state of uncertainty and tension threatening the continuity of their operations, which particularly endangers financial stability and employee maintenance. In responding to the crisis, small family firms cannot refer to previous experience or developed methods and patterns of operation.

Implications \& Recommendations: Small family businesses must quickly adapt their operations to changing conditions, regardless of their size and industry in which they operate. Covid-19 in small family businesses causes changes in their approach to running the business and family life.

Contribution \& Value Added: According to our knowledge, this is the first empirical study in Poland on the impact of Covid-19 on small family businesses.

\begin{tabular}{ll}
\hline Article type: & research article \\
Keywords: & Covid-19; pandemic; small firms; family business; entrepreneurship; crisis \\
JEL codes: & L26, L20, M10, E24
\end{tabular}

Received: 2 November $2020 \quad$ Revised: 1 April 2021 Accepted: 6 April 2021
\end{abstract}

Suggested citation:

Marjański, A., \& Sułkowski, Ł. (2021). Consolidation strategies of small family firms in Poland during Covid-19 crisis. Entrepreneurial Business and Economics Review, 9(2), 167-182. https://doi.org/10.15678/EBER.2021.090211

\section{INTRODUCTION}

We are now experiencing an exceptional situation. The unexpected impact of the Covid-19 pandemic has a significant influence on both social and economic life, changing the conditions of functioning of people as well as organizations. The governments of many countries have taken a number of severe restrictions that affected not only the functioning of the society but also national economies (Phelan et al., 2020). Firms must face diverse challenges related to the implementation of the required protection measures as well as decrease of the demand and production and supply chain disruptions (Kraus et al., 2020).

Around the world, small businesses in particular have been severely affected by the effects of Covid-19, many were forced to suspend their operations, and those that continue operating must meet a number of additional health standards and social distancing requirements. These are additional obstacles for small owners to ensure the development of their businesses, when the need for enterprise survival often comes first (Ertel, 2020). Small and medium-sized enterprises (SMEs) are quite sensitive 
to a strong economic slowdown resulting from blockades and limitations in demand. SMEs are overrepresented in many sectors that are strongly adversely affected by Covid-19. The obvious examples are rising unemployment and the bankruptcy of millions of SMEs worldwide. Forecasting the direction and depth of economic changes is difficult today due to the diverse reactions of countries and the varied course of the pandemic. Obviously, the pandemic causes significant changes in many areas of management. Many companies face serious challenges related to the possibility of continuing their operations, lack of financial resources, supply chain disruptions, and existing limitations in the work of employees (Amore et al., 2020).

The Covid-19 pandemic presents an unprecedented challenge also for small family businesses, which are an important part of the market economy. Given their widespread presence in the economy, their role is significant (Filser et al., 2016; Lušňáková et al., 2019). Owners of family businesses, where the Covid-19 pandemic has disrupted operations and often put them on the brink of recession, face uncertainty unlike any other since the two world wars (Pieper, 2020).

Family entrepreneurship is an interesting cognitive example of specific relations between the family and the business it runs. The unique character of these relations makes the functioning and development of this type of firms differ from non-family firms in many areas. Not only business factors are important in the process of managing a family firm but also the interests of the family as a whole and its individual members (Ibrahim et al., 2008). Family firms are assigned a clear specificity, usually including long-term operation optics, the implementation of specific goals, paternalistic attitude towards employees, close ties with the local environment, and a specific policy in the area of human resources. The specificity of family business results from the interpenetration of two spheres - family and business - which makes family firms not only entities with a specific form of ownership but also a separate type of firm. The fundamental feature of family firms is the concentration of ownership and management, and often the lack of separation of ownership and control in the entity. The character of the owner determines to a large extent the strategy and functioning of the family firm. Moreover, the goal of a family business differs significantly from the classic goals of a corporation, in which maximizing the value and rate of return for owners is the basic criterion for assessing the firm (Binz-Astrachan et al., 2018) as well as can impacts its internationalization processes (Głodowska, Pera, \& Wach, 2019).

Among family firms are entities of various sizes, but small firms dominate. We can estimate that about two-thirds of firms worldwide are owned, controlled, and managed by families. They provide between $60 \%$ and $90 \%$ of the global GDP (IFERA, 2003). Family businesses are characterized by considerable diversity, depending on the industry in which they operate and their individual characteristics, but small entities are the most vulnerable to the negative effects of Covid-19 (Carletti et al., 2020).

The challenges of the pandemic and its potential impact on the functioning of small family businesses are the reason that in-depth research on the economic and organizational consequences of the Covid-19 pandemic is needed. There is a lot of information on the impact of the pandemic on the economy in the media and, at the same time, a deficit of reliable research on this subject. Nonetheless, the evaluation of risks and consequences of the pandemic brought about by the spread of SARS-CoV2 virus should be both multidimensional and highly uncertain (Ragheb, 2020). An important problem is whether the changes in the world likely to be caused by the Covid-19 pandemic in the economy namely entering the recession phase, the possibility of reversing some of the effects of globalization, the so-called deglobalization, and a drastic growth of the degree of virtualization in the functioning of economies and societies - will affect the functioning of economies and societies (Androniceanu \& Tvaronavičiene, 2019). It is likely that the progressing spread of the pandemic will affect all sectors of the economy to different degrees, but the scope of losses is likely to be simultaneously very wide and multi-sectoral. The most vulnerable and therefore most affected sectors seem to be tourism, sport, hotel industry, gastronomy, culture, show business, cinematography, transport, education, and health (Albulescu, 2020; Ratten, 2020a).

We know the characteristics of small family businesses from the extensive literature on the subject and our own empirical research. Family businesses typically combine the economic logic of business strategically, structurally, and culturally with the social and emotional well-being of the owner family. With the speed with which Covid-19 has broken out and the threats it has created for all economic 
operators - not to mention the number of severe government restrictions - the current situation requires empirical research on how small family businesses respond to the crisis associated with the pandemic. Thus, the main research question of this article is:

RQ: What general changes caused by the Covid-19 pandemic can be detected in small family businesses?

In this context, we seek first preliminary information on how small family businesses in Poland reacted to the pandemic-induced crisis. The objective of this article is to contribute to research into family businesses by understanding how small family businesses are responding and adapting to the crisis.

The research method is based on the comparative analysis of case studies. The comparative sample consisted of 12 small family businesses in Poland operating in various sectors, and we conducted exploratory research based on 29 partially structured interviews with managers of these companies. Data collection techniques met the criteria of methodological triangulation using two research techniques: interviews with owners and managers and secondary data analysis (websites, strategy, organizational structure).

The structure of the article includes an attempt to present the essence of threats that Covid-19 brings to small businesses and the expected effects of the pandemic. We also indicate the challenges for small businesses to increase the virtualization of workplaces and consider whether the Covid-19 pandemic will impact the increase in globalization or whether it will do just the opposite. Moreover, we point to the very core of family entrepreneurship and its specificity resulting from the dual interaction of subsystems: family and enterprise. We also characterize small family businesses, which are the dominant form of running a business in Poland.

\section{LITERATURE REVIEW}

\section{The impact of Covid-19 on the economy and small firms}

The media coverage is dominated by suggestions claiming that the coronavirus pandemic will lead to a recession in the economy. This seems a fairly obvious observation resulting from the rising number of infections in most countries, school closings, the promotion of social distancing measures, economic lockdowns, and drastic drops in global stock markets (Ramelli \& Wagner, 2020; Pardal et al., 2020; Dias et al., 2020). The subject literature emphasizes that the Covid-19 pandemic - unlike previous crises - has many different dimensions, including economic. However, reliable studies and estimates to predict the scale of the recession are still lacking. Undoubtedly, the impact of the pandemic on the economy will be very significant, considering the scale of the epidemic and the vulnerability of the economy (Korzeb \& Niedziółka, 2020). In the corporate sector, the most vulnerable are small businesses, which due to limited financial resources, are least likely to survive the crisis (Leiva-Leon et al., 2020; Żak \& Garncarz, 2020). Some economists hoped the effect would be limited mainly to China, but this did not happen. The scale and pace of the pandemic spread has consequences for the entire global economy (Brightman et al., 2020; Ayittey et al., 2020; Khan \& Fahad, 2020; Kufel, 2020). It happened in an abrupt, unprecedented manner, and it took on a global dimension within three months (Sapovadia, 2020). Bonaparte (2000) presents three scenarios of economic consequences of the epidemic in the USA, advocating most radical interventions. As a result, Bonaparte recommends a minimum of 500 billion USD for intervention and interest rate cuts by the US Federal Reserve. In the editorial to the first issue of this year's British Medical Journal, responding to the coronavirus pandemic, Kickbusch and Leung (2020) draw attention to the decisive reaction of the Chinese authorities in fighting the pandemic, based on political decisions. It is likely that many countries will need strong governance and fast decision-making in the area of health regulations so as to be able to respond to the scale and speed of the pandemic.

Fornaro and Wolf (2020) assume that the shock caused by the coronavirus can not only lead to a supply and demand crisis but also significant adverse changes to employment and productivity. Should this scenario materialize, an intervention will be necessary to save the world economy. This is because agents are pessimistic about future productivity growth (Fetzer et al., 2020). As interest rates are below the zero level, central banks are unable to effectively counteract the economic situation. Employment 
and economic activity are both sharply dropping. Firms react by cutting capital expenditures, which has a negative impact on productivity and may consequently lead to a recession. Hence, as shown by the literature review and, more importantly, reports of financial institutions, along with the development of quarantine of the economies of individual countries, they enter the stage of stagnation or even recession. This is likely to be reflected in a global recession.

The crisis related to the Covid-19 pandemic affects the economy as a whole and the functioning of individual firms. There is great uncertainty among entrepreneurs about the future. They are also looking for new strategies to deal with the crisis (Ratten, 2020b). Its impact on small companies can be very serious, as shown by initial studies (Fairle, 2020). So far in business management, such a situation has been unprecedented, so entrepreneurs have no possibility of referring to experience or developed methods and patterns. Small firms are characterized by low resilience and are not prepared for a prolonged state of uncertainty and tension threatening business continuity, which may ultimately lead to the closure of the company. A particular threat to small businesses is the lack of financial stability and retention of employees. Moreover, firms lack knowledge about the possibilities of using the assistance offered by the government (Bartik et al., 2020). In the case of entrepreneurs running family businesses, this situation influences changes in thinking and approach to family life and running a business in order to make companies more resistant to the pandemic.

During the Covid-19 pandemic, the issue of work virtualization gained in importance. A revolution in dominant modes of communication is happening as a result of the rapid spread of the virus. Health security reasons made business, education, and even central and local administration move to online communication. It is a profound change that includes technical infrastructure and software, which shapes new social and cultural patterns. The transition to online communication methods seem to happen at a rapid pace, involving training, motivating, and monitoring of employees.

In business, there is a rapid growth of virtualization processes. New digital tools are introduced more and more widely, and the digital transformation involves a growing number of firms (Rymarczyk, 2021; Leonardi, 2020; Hradecka, 2019; Pini, 2019). It is not just schools and universities that are radically transforming education by moving to online communication, distant modes of providing educational services, and learning management systems. A number of these methods are increasingly used in business activities. Similar processes occur in the area of e-government, where most activities begin to be performed online (Tian et al., 2020). The use of digital technologies appears to be one of the major changes brought about by the Covid-19 pandemic. The opportunities provided by digital technologies are increasingly appreciated in human relations, information flow, and productivity. For many international ventures, the increasing use of digital technologies means greater reach, better coordination and lower costs (Zahra, 2020). The pandemic will result in a rapid and progressive virtualization of economic and social life. When the pandemic ends, the migration of entire sectors of the economy and administration to the network may indeed slow down, but changes in habits, lowered operating costs, and the infrastructure created will leave virtualization stronger than before.

Furthermore, in the case of small firms, the pandemic caused the problem of increasing the scope of work virtualization to become particularly important. In many industries, the use of information technology and online contacts was necessary to run the business. The development of information technologies creates the possibility of introducing new forms of the organization of firms, allowing for the maintenance or increase of competitiveness. Virtualization enables small firms to quickly react to changes and ensure efficient functioning in the market despite pandemic-induced limitations (Kraus et al., 2020; Marona \& Tomal, 2020). As a rule, small firms are limited by their resources, which makes it difficult to implement the latest technologies and develop virtualization processes. This translates into a slow implementation of advanced technological solutions. However, the adoption of these solutions, even if they occur involuntarily, shows that their implementation allows for the development of a survival strategy and maintenance of competitive advantage despite disruptions caused by the pandemic. Thus, the digitization of small business operations seems inevitable (Akpan et al., 2020; Kuc-Czarnecka, 2020; Novak, Masner, Vaněk, Šimek, \& Hennyeyová, 2020; Sieja \& Wach, 2019).

Another noteworthy problem is whether the Covid-19 pandemic will contribute to an increase in globalization or, quite the opposite, it will strengthen deglobalization tendencies. Both options 
are possible. The increase in globalization can be explained by the above structural trends. Recession, the virtualization of communication, and the growing need to coordinate epidemiological, health, and medical efforts among countries may force national governments and international organizations to strengthen cooperation on a global scale. On the other hand, deglobalizing tendencies may also gain an advantage (Balsa-Barreiro et al., 2020; Kozlov \& Sokolova 2020; He et al., 2020; Hallová, Polakovič, Šilerová, \& Slováková, 2019). However, it is already apparent that the pandemic has introduced major changes to the global business environment that will heavily affect companies in the years to come. So far, these include: the destruction of long-term relationships and networks of personal connections, the transformation of global supply chains, and the limitation of the flow of knowledge, technology, and people (Zahra, 2020).

At the present stage of the pandemic's development, national governments clearly play a leading role. They decide in matters of health and public policy regarding the introduction of emergency state (e.g. Slovakia), the division of the country into zones threatened by the pandemic (China, Italy), border closure, forced quarantine, the isolation of citizens, the construction of hospitals, the mobilization of healthcare, the army, and others services. The role of other institutions, such as the World Health Organization, churches, and the European Union is complementary (Androniceanu, 2020). In this sense, governments will generally emerge from the pandemic crisis with greater power compared to the pre-crisis period.

At the current stage of the crisis, different states make their own choices, deciding to choose more radical health and public policies (e.g. China, South Korea, Poland) or actions of a smaller scale (e.g. the UK, USA). Moreover, countries primarily rely on their own healthcare resources and national occupational health and safety systems. If there are no coordinated international actions, we may speak of the absolute domination of the fight against the pandemic at the national level with the use of international experience. Hopefully, the development of work on vaccines and drugs is more international and supported by open access to medical publications on the coronavirus. Therefore, we cannot satisfactorily answer whether the expected effects of the pandemic will deepen globalization or deglobalization.

International business is associated with large firms, but many small businesses operate on international markets by participating in a global network of connections. As a result, they enjoy many benefits due to the elimination of limitations resulting from economies of scale. More and more often they cooperate with entities in other countries, and often even on other continents (Foghani et al., 2017). The Covid-19 pandemic could lead to the cessation of operations in international markets as the barriers associated with the imposed restrictions may be too great for a small company to overcome.

\section{The essence of family entrepreneurship}

Entrepreneurship is one of the key forces shaping the economy (Chowdhury et al., 2019; Zajkowski \& Domańska, 2019). It is the vehicle through which the economic system is introduced (Meyer \& Krüger, 2021), which is why one underlines the role of higher education in shaping entrepreneurial competencies (Solesvik, 2019). The phenomenon of entrepreneurship is extremely diverse and perceived in various contexts. One of its areas is family entrepreneurship, which is the oldest and most natural form of entrepreneurship, recorded in all cultures and historical periods (Gasson et al., 1988; Obloj, 2019). It also provides an example that many business entities are created by family members and use their human, physical, and financial resources (Aldrich \& Ruef, 2006). A characteristic feature of family entrepreneurship is a strong relationship with one or more families, which determines both the functioning and firms' directions of development (Ben Moussa \& Kerkeni, 2021). Most family businesses belong to SMEs, which is also an important factor influencing their development process (Cristiano, 2017).

A common feature of family businesses is the constant and multi-faceted relationship between the business and the owner family. Astrachan (2003) recognizes that the family is a critical variable that allows for understanding the essence of a family business. Handler (1989) identifies the key factors that distinguish a family business: the concentration of ownership in the hands of family members, participation in management, and the involvement of more than one generation in running the business. The uniqueness of family firms is visible in their operation, where there is a combination of economic goals, the implementation of owner family's goals and the multigenerational perspective of creating the value of an enterprise (Sułkowski et al., 2018). 
In family firms, there is a dual interaction of two subsystems: family and enterprise. This situation significantly affects management style and directions of its development (Moss et al., 2014). Moreover, it causes decisions and actions to reflect the assumption - which is not formally stated - about maintaining the constant participation of the family in running the company and striving to pass the business on to the next generation (Lumpkin \& Brigham, 2011). The participation of the family in the functioning and creation of directions for the development of a firm is a medium that is not subject to fashions and changing trends of universal values (Wilson et al., 2014). Besides, these firms have lower threats of negative internal relationship development, like discrimination and inequality with appropriate losses in performance (Bilan, Mishchuk, Samoliuk, \& Mishchuk, 2020). The participation of the family also allows family businesses to create strategic orientations aimed at creating a competitive advantage manifested in the long-term development of basic competences and the development of organizational culture and relations with stakeholders (Miller \& Le Breton-Miller, 2006). These relations positively contribute to the corporate social responsibility maintenance and development (Çera, Belas, Marousek, \& Çera, 2020), along with employer brand strengthening (Bite \& Konczos-Szombathelyi, 2020). Strategic orientation must also include the owners' family's concern for intergenerational continuity and consider socio-emotional factors that affect the development of the entity (Gómez-Mejía et al., 2007).

A specific distinguishing feature of family entrepreneurship is intergenerational succession, which allows for the continuity of company operations thanks to its transfer to the next generation of the owner family. It is perceived as a process of transferring ownership and management from the current generation to younger successors (Bertschi-Michel et al., 2019). However, differences among family businesses include both current activities, strategic orientation and behaviour, competitive advantage shaping, and approach to creating material resources (Hoy, 2014). Like all other economic entities, family firms must adapt to changes happening on the market and face new challenges affecting their functioning and strategy in order to ensure business continuity and development. The progressing globalization means that family firms' strategic orientation should focus on introducing innovations that allow them to adapt to market requirements and internationalization (Steinerowska-Streb \& Głód, 2020; Wach, 2017; Głodowska, Pera, \& Wach, 2019). Some researchers observed that family firms internationalize faster than other firms (Maciejewski \& Wach, 2019). Furthermore, the family nature of these firms means that they are subject to a number of processes typical only for them, including the combination of ownership, management, and succession.

Due to the multifaceted connection of the family and business system, scholars pay increasingly more attention to the theoretical complexity of research issues and the need for an appropriate methodological approach in empirical research (Wilson et al., 2014). In this context, family involvement in running a business resulted in a number of paradoxes that are evident in ownership, management, and financing (Sharma et al., 2014).

\section{Characteristics of small family businesses in Poland}

The intensive development of family entrepreneurship in Poland is one of the effects of the emergence of a free market economy in Poland and the creation of opportunities for the development of private businesses (Bednarz et al., 2017). The political and economic changes initiated in 1989 allowed many to freely initiate and develop private economic activity (Sułkowski \& Marjański, 2015). This period saw unprecedented economic growth, making Poland an attractive emerging market in Central and Eastern Europe (Klonowski et al., 2008). Currently, Polish economy in many areas is comparable to countries with a stable market economy. The enterprise sector generates $75 \%$ of gross domestic product, of which SME companies generate approximately $48 \%$ and micro-enterprises approximately $30 \%$. The analysis of Eurostat data indicates that the share of the SME sector in Poland is at a similar level to the average for the European Union countries (PARP 2020). A representative survey of family businesses from the SME sector allows establishing that they constitute approximately $80 \%$ of all SMEs that operate in Poland (Sułkowski et al., 2009).

The development of the market system in Poland was an impulse to establish family businesses. The development of family businesses is a phenomenon of Polish entrepreneurship and has become one of the key successes of the Polish economy. The dominant environment for the functioning of 
these entities is the SME sector. The activity of Polish family businesses has a positive effect on the stability of economic and social development. They have a significant share in both the creation of GDP and a large number of stable jobs. The specific features of family businesses are also increasingly appreciated, such as ethical operation, teamwork skills development, building community and loyalty, but also the ability to combine professional and family life (Marjański \& Sułkowski, 2019).

We conducted research programs in 2009-2010, 2014-2016, and 2017-2018, which allowed for the collection of many observations that enable the identification of Polish small family firms' specificity and the directions of their development. We applied quantitative and qualitative approach in the research conducted in 2009-2010. In subsequent studies, we employed a qualitative approach (in-depth interviews and case studies). Research samples included: $n=1,280$ family and non-family entities in 2009-2010; $n=10$ family businesses in 2014-2016; and twice $n=20$ companies families in 2017-2018.

The first of the studies was also the first representative study aimed at obtaining data on the share of Polish family firms in the SME sector and in the creation of GDP and jobs. Thanks to the research, we could establish many specific features of Polish small family businesses. In terms of structural features - such as the scope of activity, the number of employees, the turnover or scope of investments - family businesses do not differ significantly from non-family SMEs. On the other hand, the specificity of the surveyed family businesses is visible in the sphere of values, organizational culture, the level of trust, social capital, strategy, the hierarchy of goals, and also in the approach to using the family's financial and material resources. It was also important to determine whether - regardless of the type of activity - family businesses have common features influencing the shaping of their system of values, identity, organizational culture, and family social capital. An important finding was the fact that the premise of being a family business was emphasized in different ways in the surveyed companies (Sułkowski et al., 2009).

In subsequent studies, we used qualitative methods. In 2014-2016, we studied the phenomenon of social capital in family SMEs. We wanted to find out why low social capital in Poland positively correlates with the creation and development of family SMEs and why the high level of family social capital stimulates the development of family SMEs. The key research methods were in-depth interview and participant observation. During this research, we encountered problems related to getting the respondents to reflect and establish communication with the researcher. Thanks to the achievement of the research goal, we learned about important and complex issues related to family social capital. The nature of the social capital of family SMEs in Poland motivates the families to achieve success together with the simultaneous limitation of showing family emotions in the firm. Integration, common value systems, trust, and knowledge sharing result from the high level of social capital in the surveyed firms (Marjański et al., 2019). The conclusions from the study indicate that a high level of social capital significantly stimulates the development and facilitates the company's recovery from a crisis situation. The respondents indicated that the owner family takes steps to get the company out of the crisis and, if necessary, reduces the collection of funds from the company to the absolute minimum or even transfers private savings to the company.

The 2017-2018 study attempted to identify the specificity of strategic orientation and the influence of family character on its development. The results indicate a crucial influence of family character on the shaping of strategic orientation and that the family character of the company is an important strategic factor that increases the firm's and the owner family's chances of success. Moreover, thanks to the family character of the company, valuable and scarce human resources are gained - based on trust - but also valuable material and financial resources. Familism also influenced the easier development of knowledge resources and care for the company's reputation (Marjański, 2018).

In the same period, we conducted a study aimed at obtaining knowledge about the influence of the family factor on the strategy of small family firms. Family character is a key factor influencing the functioning, development, and creation of family business strategies. Many studies increasingly focus on the role of the social system, such as the family and its impact on the functioning of the firm. In all the surveyed firms, we identified the significant influence of family factor on the shape of strategy, which we considered to be an important strategic factor leading to success in dimensions of business and owner family. Moreover, we noticed that the firm strategy combines the goals of 
the firm and the goals of the family. Familism enables the use of valuable human resources, social capital based on trust, along with material and financial resources in the process of creating and implementing strategies. Issues related to planning and implementing the succession process were indicated as an important element of strategy. Considering the influence of family factor in the strategy of a small firm run by a family may allow family SMEs harmonize values of the enterprise and the family (Marjański \& Sułkowski, 2018).

\section{RESEARCH METHODOLOGY}

A characteristic feature of family entrepreneurship is the area in which relations and family goals meet with relationships and features characteristic of the firm. Thus, obtaining in-depth knowledge about the functioning of family businesses is difficult. In many cases, family business managers consciously or unconsciously limit the role of factors related to the family nature of the business they run, limiting their role only to economic aspects. Therefore, thanks to the use of qualitative methods, some cases of research on family firms allow us to obtain information of interest to us because they offer explanations for posed questions, along with opinions and motives exploration, including those that are unconscious or deeply emotional.

Accounting for the unstructured type of the research problem, we decided to use qualitative methods in the study. The research methodology was based on 12 case studies of small family businesses from Poland. Small firms that declared themselves to be family firms were invited to the research. The research method based on a comparative analysis of case studies. A comparative sample consisted of 12 small family businesses in Poland operating in various sectors. We conducted exploratory research based on 29 partially structured interviews with owners and management. Thus, we could observe both similarities and differences in individual cases. Data analysis was performed immediately after each interview, until we concluded that further data collection brought no new insights.

Data collection techniques met criteria of methodological triangulation by the use of two research techniques: interviews with owners and managers and secondary data analysis (websites, strategy, organizational structure). As a result, we could obtain information related to the impact of the Covid19 pandemic on the functioning of a small family business. The structure of the sample, the date of the study, and the acronym of the researcher are presented in Table 1 below. Due to the need to maintain social distancing, the interviews were conducted by phone and with the use of Microsoft Teams software. The interviews were recorded upon consent of the respondents and then transcribed.

Table 1. Characteristics of the research sample

\begin{tabular}{|l|c|c|l|l|c|}
\hline \multicolumn{1}{|c|}{ Code } & $\begin{array}{c}\text { Year of } \\
\text { establishment }\end{array}$ & Employment & \multicolumn{1}{|c|}{ Sector } & Methods & $\begin{array}{c}\text { Time } \\
\text { Researcher }\end{array}$ \\
\hline FB01 & 1973 & 12 & $\begin{array}{l}\text { Production of wooden win- } \\
\text { dows and doors }\end{array}$ & Interviews (2) & 2020.06 LS \\
\hline FB02 & 1997 & 27 & Masonry & Interviews (3) & $2020.06 \mathrm{AM}$ \\
\hline FB03 & 1996 & 48 & Bakery & Interviews (3) & $2020.07 \mathrm{AM}$ \\
\hline FB04 & 1992 & 45 & Butchery & Interviews (2) & $2000.06 \mathrm{AM}$ \\
\hline FB05 & 2005 & 35 & Construction wholesale & Interviews (2) & $2020.07 \mathrm{AM}$ \\
\hline FB06 & 1999 & 5 & Hairdresser's & Interviews (2) & $2020.07 \mathrm{LS}$ \\
\hline FB07 & 1991 & 42 & Small arms production & Interviews (3) & $2020.07 \mathrm{AM}$ \\
\hline FB08 & 1996 & 15 & Accounting office & Interviews (2) & $2020.07 \mathrm{AM}$ \\
\hline FB09 & 1978 & 25 & Digital technique studio & Interviews (3) & $2020.06 \mathrm{LS}$ \\
\hline FB10 & 1974 & 10 & Furniture production & Interviews (2) & $2020.07 \mathrm{LS}$ \\
\hline FB11 & 1989 & 48 & Men's suit production & Interviews (3) & $2020.07 \mathrm{AM}$ \\
\hline FB12 & 2007 & 22 & Hotel & Interviews (2) & $2020.07 \mathrm{LS}$ \\
\hline
\end{tabular}

Source: own study. 
In the study, we sought an answer to what general changes caused by the Covid-19 pandemic can be detected in small family businesses? During the study, we developed the research question into the following areas:

RQ1: How did the Covid-19 pandemic affect your business and what perspectives do you have? Are the company's financial resources sufficient? Have you used government assistance?

RQ2: Has the pandemic reduced or increased the demand for your products or services? Have there been any changes to the company's product offer? How is the company doing in the economic slowdown? Is there a need to change the business model?

RQ3: Has the pandemic affected sales to foreign markets? Has it limited the possibilities of obtaining raw materials from domestic and foreign markets? Will the company operate on the domestic market only in the event of export restrictions?

RQ4: Has the pandemic influenced the introduction or increase of remote work and firm digitization? What are your plans for the future?

RQ5: How has the pandemic affected the situation of employees in the company? Was there a need to dismiss employees or shorten working time?

RQ6: What are the relations between the company and the owner family during the pandemic? Does the emotional relationship of the family with the firm facilitate or hinder the management of the Covid-19 crisis? Does the ownership of the owner family in the functioning of the company over time increase its chances of escaping the Covid-19 pandemic unscathed?

\section{RESULTS AND DISCUSSION}

The conducted research confirmed our previous experience that small family businesses may show several limitations related to the examined firms based on primary sources. In the current pandemic situation, it was particularly difficult to contact entrepreneurs and obtain their consent to conduct the study. Let us note that much of the information was disclosed by the respondents reluctantly because they considered it related to gaining a competitive advantage or know-how. The diversified level of respondents' involvement contributed to the qualitative differentiation of the research material.

In the study, we took into account the specificity of small firms resulting from their limited size and low degree of formalization, along with the fact that the surveyed firms found themselves for the first time in a pandemic situation that impacted their functioning. We realized that we must consider the sensitive area of relationship between the company and the family, along with the emotional relationship between the owner family and the firm they control. However, we know that only the use of in-depth methods would give us a chance to reach the key processes related to the Covid-19 outbreak in the surveyed companies. At the stage of conceptualizing the research project, we did not adopt any hypotheses but instead formulated general research questions that we developed in the cognitive process. Thanks to the adopted research methodology, we could establish good relations with the respondents. The interviews meetings were characterized by openness and authenticity, which allowed for a low degree of formalization. It seems that the choice of qualitative methods in the family business research allows for an in-depth and detailed understanding of the complexity of the studied phenomena and allows us to create case studies on the basis of which we could analyse the opinions of our respondents.

The crisis triggered by the Covid-19 pandemic was in each case a challenge for small family businesses. A challenge they never faced before. The pandemic has caused many serious restrictions in the functioning of both businesses and the families that manage them. In a crisis situation, companies seek strategies that allow them to adapt to the conditions resulting from the pandemic, and at the same time, they seek an enhanced exit in the long term. The crisis clearly triggered a series of unplanned 
changes. The surveyed companies observed an increase in the level of virtualization and an increase in the cohesion within the company.

RQ1: How did the Covid-19 pandemic affect your business and what perspectives do you have? Are the company's financial resources sufficient? Have you used government assistance?

The interviews show that not all companies have been affected by the Covid-19 pandemic equally. Restrictions imposed by the government also had various negative effects on the studied companies. We also noticed that with the size of the firm, the issue of maintaining financial liquidity was more articulated. Three companies - FB2, FB3, and FB5 - were found to be sufficiently liquid to endure the pandemic. In the remaining ones, measures have been initiated or implemented to reduce fixed costs and obtain government aid. However, the examined small family businesses were not prepared for a prolonged state of uncertainty that may limit their activities.

RQ2: Has the pandemic reduced or increased the demand for your products or services? Have there been any changes to the company's product offer? How is the company doing in the economic slowdown? Is there a need to change the business model?

In the examined small family firms, the reduction in demand did not apply to only two entities: FB3 and FB5. The remaining firms were affected by demand constraints to a varying extent. Companies FB6 and FB12 had to temporarily cease their activities because the government restricted their activities. Company FB11 that produces suits ceased production as shopping centres were closed and there was no outlet for the products. Two companies changed their product offer: FB 11 started sewing masks and coveralls for healthcare workers while FB9, due to the decline in orders for advertising materials, introduced protective helmets to its offer. These changes to the business model were short-lived, and after the reasons for the limitation in business subsided, both returned to the core business. Changes in the business model in the long-term perspective in the surveyed companies were not planned, but the managers predicted that in the event of a major economic slowdown, such actions would have to be undertaken.

RQ3: Has the pandemic affected sales to foreign markets? Has it limited the possibilities of obtaining raw materials from domestic and foreign markets? Will the company operate on the domestic market only in the event of export restrictions?

Among the surveyed companies, only four companies - FB 1, FB5, FB7, and FB11 - conducted export activities. In the initial period of the Covid-19 pandemic, FB7 was unable to ship supplies to the USA due to flight bans. None of the mentioned companies intended to withdraw from export activity if it were possible to continue. In the initial period, most surveyed companies experienced problems with the supply of raw materials and components for production.

RQ4: Has the pandemic influenced the introduction or increase of remote work and firm digitization? What are your plans for the future?

RQ5: How has the pandemic affected the situation of employees in the company? Was there a need to dismiss employees or shorten working time?

In only one company, FB10, three employees left. In other companies, the approach was that it is necessary to maintain a team as it was a valuable firm resource. Any decision to lay off employees was treated as a last resort. The family nature of the company had a positive effect on relations with employees. Five small family businesses interviewed - FB6, FB8, FB9, FB 11, and FB12 - used reduced working hours. In most of the surveyed companies, communication with employees was strengthened by informing them about the current situation. Companies FB1, FB2, FB7 and FB 11 paid attention to the high solidarity and commitment of employees to the company's affairs, which manifested in the motivation and willingness to jointly face the Covid-19 pandemic. In FB 12, employees showed understanding for the actions taken to secure the company's liquidity and survival. 
RQ6: What are the relations between the company and the owner family during the pandemic? Does the emotional relationship of the family with the firm facilitate or hinder the management of the Covid-19 crisis? Does the ownership of the owner family in the functioning of the company over time increase its chances of escaping the Covid-19 pandemic unscathed?

During the pandemic, the surveyed firms focused on getting the firm through the crisis. Family members involved in running the business were willing to sacrifice short-term gains for the long-term survival of the business. In five cases - FB1, FB6, FB10, FB11, and FB 12 - owners' personal financial resources were mobilized to ensure the continuous operation of the firm. We may conclude that the emotional relationship of the family with the company during the crisis positively influenced the involvement of family members and increased the company's resistance to the difficulties caused by the Covid-19 pandemic. Having one decision-making centre and a low degree of formalization, small family businesses can react quickly and decisively to the current pandemic situation.

\section{CONCLUSIONS}

Our article presents the first study related to the impact of the Covid-19 pandemic on small family businesses in Poland. The Covid-19 crisis poses a difficult challenge for small family businesses. Each company has been affected to some extent by the effects of the pandemic. These companies must quickly adapt to the new reality. It is certain that the crisis does not affect all firms equally. Our analysis shows that small family businesses use different approaches to deal with this crisis situation. What is important is the industry, which determines the extent to which a company is affected by the pandemic. Moreover, the scale of business activity plays a significant role in this regard.

Considering family businesses' specifics, there is a visible consolidation of family members in the drive to lead the company through the Covid-19 pandemic and to preserve the business for the next generation. The emotional relationship of the family with the company during a crisis positively influences the involvement of family members and increases the company's resistance to the difficulties caused by the Covid-19 pandemic. Let us note that the examined small family firms are not prepared for the prolonged state of uncertainty and tension threatening the continuity of their operations, and the lack of financial stability is a particular threat.

There is also a visible concern for keeping employees. Most of the companies surveyed did not have enough cash at the onset of the pandemic. However, they used government assistance and financial resources accumulated by family members. None of the companies plan to declare bankruptcy and lay off employees. However, it seems that the Covid-19 pandemic will bring about lasting changes in the functioning of small family businesses in Poland.

It is evident that the Covid-19 pandemic became a catalyst for the level of work virtualization and digital transformation that facilitates contact with customers and suppliers. In a crisis situation, small family businesses must look for new ways to use their key competences and expand their business models in line with emerging opportunities.

The results of the research indicate that the goal of a small family business is not only to survive the crisis but also to emerge from it stronger. The multigenerational perspective of running a business is an encouragement to face the challenge of the Covid-19 pandemic.

The Covid-19 pandemic is bound to become the subject of many interesting studies in the future, seeking answers to what its effects are and how it influences the functioning and development of small businesses. The article only pinpoints the threads of the pandemic-induced recession, the virtualization of the economy and society, effective support policies, and the pandemic's impact on globalization. There is no doubt that what we direly require in the era of entrepreneurial economy (Sieja \& Wach, 2019) is public support for entrepreneurial education (Nowiński et al., 2020; Wach \& Bilan, 2021). Naturally, the limitation of the article is its speculative nature as it basically relies on the literature about the social, economic, and cultural effects of the pandemic's development. We are aware of 
our study's limitations resulting from the limited size of the research sample and the meagre possibilities of inference. Our qualitative study provides only preliminary findings from the examination of twelve small family businesses from Poland. However, it did allow us to present a more accurate picture of reality, especially when the reality of the pandemic, which is to be diagnosed in more detail. In this context, we hope our work will usher in new research on how small family businesses can deal with the Covid-19 pandemic.

\section{REFERENCES}

Akpan, I.J., Soopramanien, D., \& Kwak, D.H. (2020). Cutting-edge technologies for small business and innovation in the era of COVID-19 global health pandemic. Journal of Small Business \& Entrepreneurship, 1-11. https://doi.org/10.1080/08276331.2020.1799294

Albulescu, C. (2020). Coronavirus and financial volatility: 40 days of fasting and fear. ArXiv:2003.04005, 1-7.

Aldrich, H.E., \& Ruef, M. (2006). Organizations Evolving. London: Sage.

Amore, M.D., Quarato, F., \& Pelucco, V. (2020). Family Ownership During the Covid-19 Pandemic. CEPR Discussion Paper No. DP14759, 1-25.

Androniceanu, A. (2020). Major structural changes in the EU policies due to the problems and risks caused by COVID-19. Administratie si Management Public, 34, 137-149. https://doi.org/10.24818/amp/2020.34-08

Androniceanu, A., \& Tvaronavičienè, M. (2019). Developing a holistic system for social assistance services based on effective and sustainable partnerships. Administratie si Management Public, 33, 103-118. https://doi.org/10.24818/amp/2019.33-06

Astrachan, J. (2003). Commentary on the special issue: The emergence of a field. Journal of Business Venturing, 18(5), 567-572.

Ayittey, F.K., Ayittey, M.K., Chiwero, N.B., Kamasah, J.S., \& Dzuvor, C. (2020). Economic impacts of Wuhan $2019-$ $\mathrm{nCoV}$ on China and the world. Journal of Medical Virology, 2(5), 473-475. https://doi.org./10.1002/jmv.25706

Balsa-Barreiro, J., Vié, A., Morales, A.J., \& Cebrián, M. (2020). Deglobalization in a hyper-connected world. Palgrave Communications, 6(28), 1-4. https://doi.org/10.1057/s41599-020-0403-x

Bartik, A.W., Bertrand, M., Cullenc Z., Glaeserd, E.L, Lucac, M., \& Stanton, C. (2020). The impact of Covid-19 on small business outcomes and expectations. PNAS, 117(30), 17656-17666.

Bednarz, J., Bieliński, T., Nikodemska-Wołowik, A.M., \& Otukoya, A. (2017). Sources of the Competitive Advantage of Family Firms: An International Approach Focusing on China, Nigeria and Poland. Entrepreneurial Business and Economics Review, 5(2), 123-142. https://doi.org/10.15678/EBER.2017.050207

Bertschi-Michel, A., Sieger, P., \& Kammerlander, N. (2019). Succession in family-owned SMEs: the impact of advisors. Small Business Economics, 1-21. https://doi.org/10.1007/s11187-019-00266-2

Bilan, Y., Mishchuk, H., Samoliuk, N., \& Mishchuk, V. (2020). Gender discrimination and its links with compensations and benefits practices in enterprises. Entrepreneurial Business and Economics Review, 8(3), 189-204. https://doi.org/10.15678/EBER.2020.080311

Binz-Astrachan, C., Botero, I.C., Astrachan, J.H., \& Prügl, R. (2018). Branding the family firm: a review of foundations, current knowledge, and avenues for further research. Journal of Family Business Strategy, 9(2), 1-13.

Bite, P., \& Konczos-Szombathelyi, M. (2020). Employer branding concept for small- and medium-sized family firms. Journal of International Studies, 13(3), 143- 160. https://doi.org/10.14254/2071-8330.2020/13-3/10

Bonaparte, Y. (2020). Pricing the Economic Risk of Coronavirus: A Delay in Consumption or a Recession? Available at SSRN: 3549597, 1-8. https://doi.org/10.2139/ssrn.3549597

Brightman, C., Treussard, J., \& Ko, A. (2020). Oh My! What's This Stuff Really Worth? Retrieved from https://www.researchaffiliates.com/en_us/publications/articles/787-oh-my-whats-this-stuff-reallyworth.pdf. on March 10, 2020.

Carletti, E., Oliviero, T., Pagano, M., Pelizzon, L., \& Subrahmanyam, M.G. (2020). The Covid-19 Shock and Equity Shortfall: Firm-Level Evidence from Italy. CEPR Discussion Paper No. DP14831, 1-35.

Çera, G., Belas, J., Marousek, J., \& Çera, E. (2020). Do size and age of small and medium-sized enterprises matter in corporate social responsibility?. Economics and Sociology, 13(2), 86-99. https://doi.org/10.14254/2071789X.2020/13-2/6 
Chowdhury, F., Audretsch, D.B. \& Belitski, M. (2019). Institutions and Entrepreneurship Quality. Entrepreneurship Theory and Practice, 43(1), 51-81. https://doi.org/10.1177/1042258718780431

Cristiano, E. (2017). Specific Features of Family Businesses: A Contribution to Literature. In M. Bilgin, H. Danis, E. Demir, \& U. Can (Eds.), Financial Environment and Business Development (pp. 577-600). Cham: Springer.

Dias, R., Teixeira, N., Machova, V., Pardal, P., Horak, J., \& Vochozka, M. (2020). Random walks and market efficiency tests: evidence on US, Chinese and European capital markets within the context of the global Covid19 pandemic. Oeconomia Copernicana, 11(4), 585-608. https://doi.org/10.24136/oc.2020.024

Loan, L.T., Doanh, D.C., Thang, H. N., Viet Nga, N.T., Van, P.T., \& Hoa, P.T. (2021). Entrepreneurial behaviour: The effects of fear and anxiety of Covid-19 and business opportunity recognition. Entrepreneurial Business and Economics Review, 9(3). Ahead-of-Print. First online.

Ertel, S. (2020). Small Business Post-Covid-19: Motivational Needs through Uncertain Times. Compensation \& Benefits Review. 1-8. https://doi.org/10.1177/0886368720945134

Fairle, R.W. (2020). The Impact of Covid-19 on Small Business Owners: Evidence of Early-Stage Losses from the April 2020 Current Population Survey. NBER Working Paper No. 27309, 1-21.

Fetzer, T., Hensel, L., Hermle, J., \& Roth, C. (2020). Perceptions of Coronavirus Mortality and Contagiousness Weaken Economic Sentiment. ArXiv:2003.03848, 1-60.

Filser, M., Brem, A., Gast, J., Kraus, S., \& Calabro, A. (2016). Innovation in family firms-examining the inventory and mapping the path. International Journal of Innovation Management, 20(6), 1-39.

Foghani, S., Mahadi, B., \& Omar, R. (2017). Promoting Clusters and Networks for Small and Medium Enterprises to Economic Development in the Globalization Era. SAGE Open, 7(1), 1-9. https://doi.org/10.1177/2158244017697152

Fornaro, L., \& Wolf, M. (2000). Covid-19 Coronavirus and Macroeconomic Policy. CEPR Discussion Paper. No. DP14529, 1-12. Available at SSRN: 3560337.

Gasson, R., Crow, W., Errington, A., Hutson, J., Marsden, T., \& Winter, D.M. (1988). The farm as a family business: a review. Journal of Agricultural Economics, 39(1), 1-41.

Głodowska, A., Pera, B., \& Wach, K. (2019). International strategy as the facilitator of the speed, scope, and scale of firms' internationalization. Central European Management Journal, 27(3), 55-84. http://dx.doi.org/10.7206/cemj.2658-0845.3

Gómez-Mejía, L.R., Haynes, K.T., Núñez-Nickel, M., Jacobson, K.J.L., \& Moyano-Fuentes, J. (2007). Socioemotional wealth and business risks in family controlled firms: Evidence from Spanish olive oil mills. Administrative Science Quarterly, 52(1), 106-137.

Hallová, M., Polakovič, P., Šilerová, E., \& Slováková, I. (2019). Data Protection and Security in SMEs under Enterprise Infrastructure. AGRIS on-line Papers in Economics and Informatics, 11(1), 27-33. https://doi.org/10.7160/aol.2019.110103

Handler, W.C. (1989). Methodological issues and considerations in studying family businesses. Family Business Review, 2(3), 257-276.

He, L.Y., Lin, X., \& Zhang, Z. (2020). The impact of de-globalization on China's economic transformation: Evidence from manufacturing export. Journal of Policy Modeling, 42(3), 628-660. https://doi.org/10.1016/j.jpolmod.2020.02.001

Hoy, F. (2014). Entrepreneurial Venturing for Family Business Research. In L. Melin, M. Nordqvist, \& P. Sharma (Eds.), The Sage Handbook of Family Business (pp. 620-628). Los Angeles: Sage.

Hradecká, M. (2019). Robotic Internal Audit - Control Methods in the Selected Company. AGRIS on-line Papers in Economics and Informatics, 11(2), 31-42. https://doi.org/10.7160/aol.2019.110204

Ibrahim, N.A., Angelidis, J.P., \& Parsa, F. (2008). Strategic management of family businesses: current findings and directions for future research. International Journal of Management, 25(1), 95-110.

International Family Enterprise Research Academy (2003). Family businesses dominate. Family Business Review, 16(4), 235-240.

Khan, N., \& Fahad, S. (2020). Critical Review of the Present Situation of Corona Virus in China. Available at SSRN: 3543177, 1-31. https://doi.org/10.2139/ssrn.3543177

Kickbusch, I., \& Leung, G. (2020). Response to the emerging novel coronavirus outbreak. BMJ, 368, 1-2. https://doi.org/10.1136/bmj.m406 
Klonowski, D., Power, J.L., \& Linton, D. (2008). The Development of Franchise Operations in Emerging Markets: The Case of a Poland-Based Restaurant Operator. Cornell Hospitality Quarterly, 49(4), 436-449. https://doi.org/10.1177/1938965508324294

Korzeb, Z., \& Niedziółka, P. (2020). Resistance of commercial banks to the crisis caused by the COVID-19 pandemic: the case of Poland. Equilibrium. Quarterly Journal of Economics and Economic Policy, 15(2), $205-234$. https://doi.org/10.24136/eq.2020.010

Kozlov, N., \& Sokolova, N. (2020). Deglobalization: The Impact of the External Environment on Russian Economic Development. Norwegian Journal of Development of the International Science, 38(2), $20-22$.

Kraus, S., Clauss, T., Gast. J., Zardini, A., \& Tiberus, V. (2020). The economics of Covid-19: initial empirical evidence on how family firms in five European countries cope with the corona crisis. International Journal of Entrepreneurial Behavior \& Research, 26(5), 1067-1092. https://doi.org/10.1108/IJEBR-04-2020-0214

Kuc-Czarnecka, M. (2020). COVID-19 and digital deprivation in Poland. Oeconomia Copernicana, 11(3), 415-431. https://doi.org/10.24136/oc.2020.017

Kufel, T. (2020). ARIMA-based forecasting of the dynamics of confirmed Covid-19 cases for selected European countries. Equilibrium. Quarterly Journal of Economics and Economic Policy, 15(2), 181-204. https://doi.org/10.24136/eq.2020.009

Leiva-Leon, D., Pérez-Quirós, G., \& Rots, E. (2020). Real-Time Weakness of the Global Economy: A First Assessment of the Coronavirus Crisis. ECB Working Paper. No. 2381. 1-60.

Leonardi, P. (2020). You're Going Digital-Now What?. MIT Sloan Management Review, 61(2), 28-35.

Lumpkin, G.T., \& Brigham, K.H. (2011). Long-term orientation and intertemporal choice in family firms. Entrepreneurship Theory and Practice, 35(6), 1149-1169. https://doi.org/10.1111/j.1540-6520.2011.00495.x

Lušňáková, Z., Juríčková, Z., Šajbidorová, M., \& Lenčéšová, S. (2019). Succession as a sustainability factor of family business in Slovakia. Equilibrium. Quarterly Journal of Economics and Economic Policy, 14(3), 503-520. https://doi.org/10.24136/eq.2019.024

Maciejewski, M., \& Wach, K. (2019). International Startups from Poland: Born Global or Born Regional?. Journal of Management and Business Administration Central Europe, 27(1), 60-83. https://doi.org/10.7206/jmba.ce.2450-7814.247

Marjański, A., \& Sułkowski, Ł. (2019). The Evolution of Family Entrepreneurship in Poland: Main Findings Based on Surveys and Interviews from 2009-2018. Entrepreneurial Business and Economics Review, 7(1), 95-116. https://doi.org/10.15678/EBER.2019.070106

Marjański, A. (2018). Strategic Orientation in the Family Enterprise Development Process. Organization Review, 11, 36-42. https://doi.org/10.33141/po.2018.11.05

Marjański, A., \& Sułkowski, Ł. (2018). Influence of family spirit on the development of family business strategy. Research Papers of Wroclaw University of Economics, 538, 216-224. https://doi.org/10.15611/pn.2018.538.17

Marjański, A., Sułkowski, Ł., Marjańska-Potakowska, J., \& Staniszewska, K. (2019). Social capital drives SME growth: A study of family firms in Poland. German Journal of Human Resource Management, 33(3), 280-304. https://doi.org/10.1177/2397002219847668

Marona, B., \& Tomal, M. (2020). The COVID-19 pandemic impact upon housing brokers' workflow and their clients' attitude: Real estate market in Krakow. Entrepreneurial Business and Economics Review, 8(4), 221-232. https://doi.org/10.15678/EBER.2020.080412

Meyer, N., \& Krüger, N. (2021). South African female entrepreneurs' motivational factors: Differences between young and established businesses owners. Forum Scientiae Oeconomia, 9(1), 75-90. https://doi.org/10.23762/FSO_VOL9_NO1_5

Miller, D., \& Le Breton-Miller, I. (2006). The best of both worlds: Exploitation and exploration in successful family businesses. Advances in Strategic Management, 23, 215-240. https://doi.org/10.1016/S07423322(06)23007-9

Moss, T.W., Payne, G.T., \& Moore, C.B. (2014). Strategic Consistency of Exploration and Exploitation in Family Businesses. Family Business Review, 27(1), 51-71. https://doi.org/10.1177/0894486513504434

Novák, J.Š., Masner, J., Vaněk, J., Šimek, P., \& Hennyeyová, K. (2019). User Experience and Usability in Agriculture - Selected Aspects for Design Systems. AGRIS on-line Papers in Economics and Informatics, 11(4), 75-83. https://doi.org/10.7160/aol.2019.110407 
Nowiński, W., Haddoud, M., Wach, K., \& Schaefer, R. (2020). Perceived public support and entrepreneurship attitudes: A little reciprocity can go a long way! Journal of Vocational Behavior, 121, 103474. https://doi.org/10.1016/j.jvb.2020.103474

Obloj, K. (2019). Footnotes to organizational competitiveness. Economics and Business Review, 19(3), 35-49. https://doi.org/10.18559/ebr.2019.3.3

Pardal, P., Dias, R., Šuleř, P., Teixeira, N., \& Krulický, T. (2020). Integration in Central European capital markets in the context of the global COVID-19 pandemic. Equilibrium. Quarterly Journal of Economics and Economic Policy, 15(4), 627-650. https://doi.org/10.24136/eq.2020.027

PARP. (2020). Report on the condition of small and medium-sized enterprise sector in Poland. Warsaw: Polish Agency for Enterprise Development.

Phelan, A.L., Katz, R., \& Gostin, L.O. (2020). The novel coronavirus originating in Wuhan, China: challenges for global health governance. Jama, 323(8), 709-710. https://doi.org/10.1001/jama.2020.1097

Pieper, T.M. (2020). Editor's note. Journal of Family Business Strategy, 11(2), 1-3. https://doi.org/10.1016/j.jfbs.2020.100362

Ragheb, M. (2020). Probabilistic, Possibilistic and Deterministic Safety Analysis. Retrieved from https://mragheb.com/NPRE\%20457\%20CSE\%20462\%20Safety\%20Analysis\%20of\%20Nuclear\%20Reactor\%20Systems/Risk\%20Quantification.pdf. on May 25, 2020.

Ramelli, S., \& Wagner, A.F. (2020). Feverish Stock Price Reactions to Covid-19. Review of Corporate Finance Studies, Swiss Finance Institute Research Paper, 20(12), 1-57. https://doi.org/10.2139/ssrn.3550274

Ratten, V. (2020a). Coronavirus disease (COVID-19) and sport entrepreneurship. International Journal of Entrepreneurial Behavior \& Research, 26(6), 1379-1388. https://doi.org/10.1108/IJEBR-06-2020-0387

Ratten, V. (2020b). Coronavirus (covid-19) and entrepreneurship: changing life and work landscape. Journal of Small Business \& Entrepreneurship, 32(5), 503-516. https://doi.org/10.1080/08276331.2020.1790167

Sapovadia, V.K. (2020). Terrestrial and Celestial Forces Expose Vulnerable Economists: Financial Crisis 2008 vs. 2020. 1-8. https://doi.org/10.2139/ssrn.3547745

Sieja, M., \& Wach, K. (2019). The Use of Evolutionary Algorithms for Optimization in the Modern Entrepreneurial Economy: Interdisciplinary Perspective. Entrepreneurial Business and Economics Review, 7(4), 117-130. https://doi.org/10.15678/EBER.2019.070407

Sharma, P., Melin, L., \& Nodqvist, M. (2014). Scope, Evolution and Future of Family Business Studies. In L. Melin, M. Nordqvist, \& P. Sharma (Ed.), The Sage Handbook of Family Business (pp. 1-23). Los Angeles: Sage.

Solesvik, M. (2019). Entrepreneurial competencies and intentions: the role of higher education. Forum Scientiae Oeconomia, 7(1), 9-23. https://doi.org/10.23762/FSO_VOL7_NO1_1

Sułkowski, Ł., \& Marjański, A. (2015). Polish small and medium-sized family businesses - trajectories of success. Management \& Gouvernance, 13, 75-94.

Sułkowski, Ł., Marjański, A., \& Sułkowska, J. (2018). Entrepreneurship of family businesses in the European Union. In Alina M. Dima (Ed.), Doing Business in Europe (pp. 255-270), Cham: Springer. https://doi.org/10.1007/9783-319-72239-9_12

Sułkowski, Ł., Marjański, A., Kowalewska, A., Lewandowska, B., Kwiatkowska, M., \& Krynicki, T.J. (2009). Family Businesses and the Polish Economy - Opportunities and Challenges. Warsaw: Polish Agency for Enterprise Development.

Tian, F., Zheng, Q., \& Chao, K. (2020). Current and future of technologies and services in smart e-learning. SOCA, 14, 1-3. https://doi.org/10.1007/s11761-020-00288-9

Wach, K. (2017). Exploring the Role of Ownership in International Entrepreneurship: How does Ownership Affect Internationalisation of Polish Firms?. Entrepreneurial Business and Economics Review, 5(4), 205-224. http://doi.org/10.15678/EBER.2017.050410

Wach, K., \& Bilan, S. (2021). Public support and administration barriers towards entrepreneurial intentions of students in Poland. Administratie si Management Public, 36(1).

Wilson, S.R., Whitmoyer, J.G., Pieper, T.M., Astrahan, J.H., Hair, J.F. Jr., \& Sarstedt, M. (2014). Method Trends and Method needs: Examining Methods Needed for Accelerating, the Field. Journal of Family Business Strategy, 5(1), 4-14. https://doi.org/10.1016/j.jfbs.2014.01.011

Zahra, S.A. (2020). International entrepreneurship in the post Covid world. Journal of World Business, 56(1), 101143. https://doi.org/10.1016/j.jwb.2020.101143 
Zajkowski, R., \& Domańska, A. (2019). Differences in perception of regional pro-entrepreneurial policy: does obtaining support change a prospect?. Oeconomia Copernicana, 10(2), 359-384. https://doi.org/10.24136/oc.2019.018

Żak, M., \& Garncarz, J. (2020). Economic policy towards the challenges of the COVID-19 pandemic in selected European Union countries. International Entrepreneurship Review, 6(4), 21-34. https://doi.org/10.15678/IER.2020.0604.02

\section{Authors}

The contribution share of authors is equal and amounted to $50 \%$ for each of them.

\section{Andrzej Marjański}

Associate Professor and Deputy Dean of the Faculty of Management, Head of the Department of Entrepreneurship and Family Businesses at the University of Social Sciences in Łódź. His research interests and activities as an expert concentrate on the issues of family enterprises, development strategies, entrepreneurship, and the management of small and medium-sized enterprises.

Correspondence to: Dr. Andrzej Marjański, Department of Entrepreneurship and Family Businesses, University of Social Sciences, ul. Sienkiewicza 9, 90-113 Łódź, Poland, e-mail: amarjanski@san.edu.pl

ORCID ๑ http://orcid.org/0000-0001-6534-2632

\section{tukasz Sułkowski}

Full Professor at the Faculty of Management and Social Communication of the Jagiellonian University, at Clark University, and the Chair of the Management Department at the University of Social Sciences in Łódź, Poland. A member of the Presidium of the Polish Accreditation Committee since 2012. His research interests include organisation and management, especially critical management studies, the epistemology and methodology of social sciences and the humanities, organisational culture and intercultural management, public management, and the management of family businesses.

Correspondence to: Prof. dr hab. Łukasz Sułkowski, Institute of Public Affairs, Jagiellonian University, ul. Łojasiewicza 4, 30-348 Kraków, Poland, e-mail: lukasz.sulkowski@uj.edu.pl

ORCID $\odot$ http://orcid.org/0000-0002-1248-2743

\section{Acknowledgements and Financial Disclosure}

The research was funded by the University of Social Sciences research funds. The authors declare no potential conflicts of interest with regard to the research, authorship, and publication of this article.

\section{Conflict of Interest}

The authors declare that the research was conducted in the absence of any commercial or financial relationships that could be construed as a potential conflict of interest.

\section{Copyright and License}

This article is published under the terms of the Creative Commons

Attribution - NoDerivs (CC BY-ND 4.0) License

http://creativecommons.org/licenses/by-nd/4.0/ 